\title{
Upaya Meningkatkan Hasil Belajar Peserta Didik pada Muatan Matematika Melalui Model Discovery Learning di Kelas V SDN 146/X Tanjung Solok pada Semester Ganjil Tahun Ajaran 2021/2022
}

\author{
Sahriani \\ SDN 146/X Tanjung Solok \\ Jl. Maju Jaya RT.11 Kelurahan Tanjung Solok, Tanjung Solok, Kec. Kuala Jambi, Kab. Tanjung Jabung Timur Prov. Jambi \\ sahriani2009@gmail.com
}

\begin{abstract}
The problem in this research is that the learning outcomes of students' mathematics content are still low and there is a need for an action to improve it. The purpose of this study was to obtain information and discuss efforts to improve student learning outcomes on mathematics content through discovery learning models in class V SDN 146/X Tanjung Solok in the odd semester of the 2021/2022 academic year. This research is a classroom action research by following four stages, namely planning, implementation, observation, and reflection. The research location is at SDN 146/X Tanjung Solok in the odd semester of the 2021/2022 academic year with the research subjects being 21st grade students of SDN 146/X Tanjung Solok. Data collection techniques using tests, field notes, interviews and documentation. Data were analyzed using percentages and data reduction. Based on the results of the research and discussion, it can be concluded that through discovery learning learning models can improve the learning outcomes of the fifth grade students of SDN 146/X Tanjung Solok, which is characterized by an increase in the average learning outcome and the percentage of completeness of each cycle with the act of giving rewards.
\end{abstract}

Keywords: Learning Outcomes, Mathematics, Discovery Learning

\begin{abstract}
Abstrak
Permasalahan dalam penelitian ini adalah hasil belajar muatan matematika peserta didik yang masih rendah dan perlu adanya sebuah tindakan untuk memperbaikinya. Tujuan dari penelitian ini adalah untuk mendapatkan informasi dan membahas tentang upaya meningkatkan hasil belajar peserta didik pada muatan matematika melalui model discovery learning di kelas V SDN 146/X Tanjung Solok pada semester ganjil tahun ajaran 2021/2022. Penelitian ini merupakan penelitian tindakan kelas dengan mengikuti empat tahapan yaitu perencanaan, pelaksanaan, observasi, da refleksi. Lokasi penelitian bertempat di SDN 146/X Tanjung Solok pada semester ganjil tahun ajaran 2021/2022 dengan subjek penelitian peserta didik kelas V SDN 146/X Tanjung Solok yang berjumlah sebanyak 21 orang. Teknik pengumpulan data menggunakan tes, catatan lapangan, wawancara dan dokumentasi. Data dianalisis menggunakan persentase dan reduksi data. Berdasarkan hasil penelitian dan pembahasan dapat disimpulkan bahwa melalui model pembelajaran discovery learning dapat meningkatkan hasil belajar muatan matematika peserta didik kelas V SDN 146/X Tanjung Solok yang ditandai dengan peningkatan rata-rata hasil belajar dan persentase ketuntasan masing-masing siklus dengan tindakan pemberian reward.
\end{abstract}

Kata Kunci: Hasil Belajar, Matematika, Discovery Learning

Copyright (c) 2022 Rosianty

Corresponding author: Sahriani

Email Address: sahriani2009@gmail.com (Jl. Maju Jaya RT.11, Tanjung Solok, Tanjung Jabung Timur, Jambi)

Received 10 January 2022, Accepted 20 January 2022, Published 28 January 2022

\section{PENDAHULUAN}

Indonesia merupakan salah satu negara berkembang di dunia. Saat ini Indonesia sedang memperbaiki segala bidang demi mengikuti globalisasi. Salah satu bidang yang terus dilakukan perbaikan saat ini adalah bidang pendidikan. Sebagai dampak dari proses globalisasi, pengembangan pengajaran yang ditujukan untuk mempersiapkan individu untuk dapat menyesuaikan diri dan memecahkan masalah di lingkungannya menjadi tidak relevan lagi. Pendidikan bertujuan untuk 
menjadikan anak mampu memainkan peran sebagai makhluk individu dan makhluk sosial sesuai dengan potensi yang dimilikinya. Peningkatan kualitas anak ini tidak hanya menjadi tanggung jawab pemerintah saja tetapi juga tanggung jawab orang tua, guru dan lingkungan masyarakat. Menurut Ngalim Purwanto (2007: 85) belajar merupakan suatu perubahan tingkah laku dimana perubahan tingkah laku itu dapat mengarah kepada tingkah laku yang lebih baik. Menurut Sardiman (2008: 20) belajar merupakan perubahan tingkah laku atau penampilan dengan serangkaian kegiatan, misalnya dengan membaca, menulis, mendengarkan dan lain-lain.

Proses belajar mengajar merupakan suatu proses yang mengandung serangkaian perbuatan guru dan peserta didik atas dasar hubungan timbal balik yang berlangsung dalam situasi edukatif untuk mencapai tujuan tertentu. Menurut Usman ( 2001:4 ). Interaksi atau hubungan timbal balik antara guru dan peserta didik itu merupakan syarat utama bagi berlangsungnya proses belajar mengajar. Dalam menerapkan kurikulum 2013, Menteri Pendidikan dan Kebudayaan RI menyarankan berbagai model pembelajaran, salah satunya adalah model Discovery Learning untuk mengembangkan sikap, pengetahuan, dan keterampilan. Hal tersebut dinyatakan lagi dalam penguatan proses pembelajaran, peserta didik di arahkan untuk mencari tahu ( Discovery) bukan lagi di beri tahu.

Peserta didik yang sudah terbiasa dengan sistem mendengar atau menerima dari guru saja, maka sudah harus di mulai mengadakan perubahan-perubahan supaya peserta didik terbiasa dengan berusaha sendiri, menemukan sendiri, bukan mengharapkan masukan semata dari guru. Hal inilah yang sedang di kembangkan melalui kurikulum 2013 dengan model pembelajaran Discovery Learning. Model Discovery Learning menginginkan peserta didik yang bekerja, dan mencari tahu sendiri dengan usaha mereka sendiri. Salah satu yang dipelajari oleh peserta didik adalah muatan matematika. Pembelajaran matematika bagi para peserta didik merupakan pembentukan pola pikir dalam pemahaman suatu pengertian maupun dalam penalaran suatu hubungan diantara pengertianpengertian itu. Dalam pembelajaran matematika, para peserta didik dibiasakan untuk memperoleh pemahaman melalui pengalaman tentang sifat-sifat yang dimiliki dan yang tidak dimiliki dari sekumpulan objek.

Berdasarkan hasil observasi yang dilakukan oleh peneliti didapat hasil belajar peserta didik masih banyak yang belum tuntas atau belum mencapai KKM (68) yang ditetatpkan. Hal ini dapat dilihat pada tabel berikut ini:

Tabel 1. Rekapitulasi Hasil Belajar Peserta Didik

\begin{tabular}{|c|c|c|c|c|c|}
\hline Kelas & Nilai Rata-rata & Peserta didik & Peserta didik & \multicolumn{2}{|c|}{ \% Ketuntasan } \\
\cline { 4 - 6 } & UH 1 & yang tuntas & yang tidak tuntas & Tuntas & Tidak tuntas \\
\hline V & KKM $: 68=50.5$ & 8 orang & 13 orang & $38 \%$ & $62 \%$ \\
\hline
\end{tabular}

Berdasarkan tabel di atas maka dapat disimpukan dari 21 orang peserta didik, yang tuntas hanya 8 orang atau $38 \%$, sedangkan 13 orang lagi atau $62 \%$ belum tuntas. Hal ini berarti secara 
keseluruhan peserta didik belum tuntas belajar dilihat dari rata-rata yang didapat yaitu sebesar 50,5 atau dibawah KKM yang ditetapkan yaitu sebesar 68.

Berdasarkan hal di atas, perlu adanya peranan guru untuk melakukan perbaikan cara mengajar yang memungkinkan peserta didik terlibat secara aktif dalam belajar, sehingga hasil belajar peserta didik dapat meningkat sesuai kondisi diatas tugas seorang guru berkewajiban melakukan inovasi dalam pembelajaran matematika. Untuk itu salah satu model yang dapat digunakan adalah model pembelajaran discovery leaning yang dikemukakan oleh Jerome Bruner. Dengan menggunakan metode ini guru memberikan kesempatan atau mendorong peserta didik untuk menemukan sendiri informasi. Dalam mengaplikasikan model pembelajaran discovery learning guru berperan sebagai pembimbing dengan memberikan kesempatan kepada peserta didik untuk belajar secara aktif, sebagaimana pendapat guru harus dapat membimbing dan mengarahkan kegiatan belajar peserta didik sesuai dengan tujuan. Sehingga dengan model pembelajaran discovery learning dapat meningkatkan aktivitas belajar peserta didik. Untuk itu penulis tertarik untuk mengadakan penelitian yang bertujuan untuk mendapatkan informasi dan membahas tentang upaya meningkatkan hasil belajar peserta didik pada muatan matematika melalui model discovery learning di kelas V SDN 146/X Tanjung Solok pada semester ganjil tahun ajaran 2021/2022.

Belajar adalah usaha untuk membentuk tanggapan-tanggapan baru.pendapat ini dikemukakan oleh para ahli psikologi asosiasi. Peristiwa belajar dipandangnya sebagai peristiwa untuk menghadapi masalah-masalah berdasarkan tanggapan-tanggapan itu dan hubungan antara tanggapan-tanggapan dengan objek yang dipecahkan ( Mustaqlim, 2010: 60). Menurut Dahan ( 2012), Belajar dapat difenisikan sebagai suatu proses dimana suatu organisasi berubah berlakunya sebagai akibat pengalaman. Menurut Gangne (1984) dalam dalam Rusman, (2012) belajar dapat didefenisikan sebagai suatu proses di mana suatu organisasi berubah perilakunya sebagai akibat pengalaman . Belajar adalah suatu proses usaha yang dilakukan seseorang untuk memperoleh suatu perubahan tingkah laku yang baru secara keseluruhan, sebagai hasil pengalamannya sendiri dalam interaksi dengan lingkungannya, ( Slameto, $2010: 2$ ).

Berdasarkan pendapat diatas dapat disimpulkan belajar adalah suatu proses yang kompleks dari aksi tindakan seseorang yang akan meimbulkan terjadinya perubahan perilaku setiap orang sepanjang hidupnya. Salah satu bahwa pertanda orang itu belajar adalah adanya perubahan tingkah laku mungkin disebabkan oleh terjadinya perubahan tingkat pengetahuan, keterampilan, atau sikapnya.

Proses pembelajaran mengandung dua unsur, yaitu proses dan hasil belajar. Proses adalah kegiatan yang dilaksanakan peserta didik dalam mencapai tujuan pengajaran, sedangkan hasil belajar adalah upaya kemampuan yang dimiliki peserta didik setelah menerima pengalaman belajar. Semua hasil belajar tersebut merupakan hasil dari suatu interaksi tindak belajar dan tindak mengajar. Dari sisi guru, tindak mengajar di akhiri dengan proses evaluasi hasil belajar, sedangkan dari sisi peserta didik , hasil belajar merupakan berakhirnya puncak proses belajar (Dimyati dan Mudjiono, 2009: 3). 
Hal ini juga diperkuat menurut Sudjana (2010: 22), hasil belajar adalah kemampuan yang dimiliki peserta didik setelah menerima pengalaman belajar. Selanjutnya Warsito (dalam Depdiknas, 2006: 125) mengemukakan bahwa hasil dari kegiatan belajar ditandai dengan adanya perubahan perilaku ke arah positif yang relatif permanen pada diri orang yang belajar. Sehubungan dengan pendapat itu, maka Wahidmurni, dkk. (2010: 18) menjelaskan bahwa sesorang dapat dikatakan telah berhasil dalam belajar jika ia mampu menunjukkan adanya perubahan dalam dirinya. Perubahanperubahan tersebut di antaranya dari segi kemampuan berpikirnya, keterampilannya, atau sikapnya terhadap suatu objek.

Menurut Uno (2011:21) Hasil belajar adalah variable metode dan kondisi pembelajaran, variable hasil pembelajaran juga dapat diklasifikasikan dengan cara yang sama, pada tingkat yang amat umum sekali hasil pembelajaran dapat diklasifikasikan menjadi 3 (tiga) yaitu keefektifan, efesisensi, dan daya tarik.

Dari beberapa pendapat para ahli di atas dapat disimpulkan bahwa hasil belajar adalah hasil dari suatu interaksi tindak belajar dan tindak mengajar dan merupakan usaha sadar yang dilakukan secara sistematis mengarah kepada perubahan yang positif yang meliputi kemampuan berpikirnya, keterampilannya, atau sikapnya terhadap suatu objek.

Pembelajaran matematika adalah proses interaksi antara guru dan peserta didik yang melibatkan pengembangan pola berfikir dan mengolah logika pada suatu lingkungan belajar yang sengaja diciptakan oleh guru dengan berbagai metode agar program belajar matematika tumbuh dan berkembang secara optimal dan peserta didik dapat melakukan kegiatan belajar secara efektif dan efisien (Rusyanti, 2014). Pembelajaran Matematika adalah proses pemberian pengalaman belajar kepada peserta didik melalui serangkaian kegiatan yang terencana sehingga peserta didik memperoleh kompetensi tentang bahan matematika yang dipelajari (Sudiati, 2014). Belajar pada intinya tertumpu pada kegiatan memberi kemungkinan kepada peserta didik agar terjadi proses belajar yang efektif atau dapat mencapai hasil yang sesuai tujuan (Safarida, 2011).

Berdasarkan pendapat diatas dapat disimpulkan bahwa pembelajaran matematika adalah kegiatan belajar dan mengajar yang mempelajari ilmu 5 matematika dengan tujuan membangun pengetahuan matematika agar bermanfaat dan mampu mengaplikasikannya dalam kehidupan seharihari

Model pembelajaran adalah suatu perencanaan atau suatu pola yang digunakan sebagai pedoman dalam merencanakan pembelajaran di kelas. Model pembelajaran mengacu pada pendekatan pembelajaran yang akandigunakan, termasuk di dalamnya tujuan-tujuan pengajaran, tahap-tahap dalam kegiatan pembelajaran, lingkungan pembelajaran, dan pengelolaan kelas (Arends dalam Trianto, 2010: 51).

Menurut Trianto (2010: 53) fungsi model pembelajaran adalah sebagai pedoman bagi perancang pengajar dan para guru dalam melaksanakan pembelajaran. Untuk memilih model ini sangat dipengaruhi oleh sifat dari materi yang akan diajarkan, dan juga dipengaruhi oleh tujuan yang 
akan dicapai dalam pengajaran tersebut serta tingkat kemampuan peserta didik. Dalam buku panduan pembelajaran pendidik harus merencanakan pembelajaran sesuai tuntutan kurikulum dengan menggunakan pendekatan saintifik dan model pembelajaran yang mendorong kemampuan peserta didik untuk melakukan penyingkapan/penelitian, serta dapat menghasilkan karya kontekstual, baik individual maupun kelompok.

Metode pembelajaran discovery menuntut guru untuk lebih kreatif menciptakan situasi yang dapat membuat peserta didik belajar aktif menemukan pengetahuan sendiri. Pembelajaran discovery melalui kegiatan eksperimen dapat menambah pengetahuan dan keterampilan peserta didik secara stimulan (Sani, 2013 : 98).

Creickshank et all dalam The Act of Teaching (2009 : 262) menjelaskan tujuan discovery learning agar peserta didik mencari tahu dan menemukan sendiri, peserta didik diharapkan tidak bergantung terlalu banyak dalam menerima pengetahuan dari guru dan menerima kesimpulan dari yang lain. Tujuan kedua discovery learning untuk membantu peserta didik mengetahui bagamana pengetahuan dirumuskan.Tujuan ketiga untuk meningkatkan kemampuan berpikir peserta didik .

Model pembelajaran yang sesuai dengan penelitian ini adalah model pembelajaran discovery learning dengan penerapan model pembelajaran discovery learning ini diharapkan dapat membantu peserta didik untuk lebih aktif dan kreatif dalam mengkomunikasikan pembelajaran, menjawab pertanyaan, menyelesaikan permasalahn dengan baik. Peserta didik dikatakan berhasil apabila mampu menyelesaikan permasalahan dan memberikan jawaban (aktif) dengan baik dan benar.

\section{METODE}

Penelitian ini merupakan penelitian tindakan kelas dengan mengikuti empat tahapan yaitu perencanaan, pelaksanaan, observasi, da refleksi. Lokasi penelitian bertempat di SDN 146/X Tanjung Solok pada semester ganjil tahun ajaran 2021/2022 dengan subjek penelitian peserta didik kelas V SDN 146/X Tanjung Solok yang berjumlah sebanyak 21 orang. Teknik pengumpulan data menggunakan tes, catatan lapangan, wawancara dan dokumentasi. Data dianalisis menggunakan persentase dan reduksi data.

\section{HASIL DAN DISKUSI}

\section{Hasil Penelitian}

\section{Siklus I}

\section{Perencanaan}

Perencanaan pada siklus I terdiri dari: 1) Mempersiapkan jadwal penelitian tindakan kelas, 2) Merencanakan materi yang akan dilaksanakan pada waktu penelitian agar mengetahui kompetensi dasar yang akan disampaikan kepada peserta didik dalam pembelajaran, 3) Mempersiapkan silabus dan RPP, 4) Mempersiapkan rencana pembelajarandengan mengacu pada tindakan yang diterapkan 
dalam PTK, 5) Mempersiapkan media yang akan dipakai pada saat penelitian, 6) Mempersiapkan format Observasi.

\section{Pelaksanaan}

Pertemuan 1 siklus I dilaksanakan pada hari Senin tanggal 12 September 2021 dengan alokasi waktu 2 x 45 menit dengan materi pokok membahas tentang perkalian pecahan campuran dan perkalian berbagai bentuk pecahan. Tujuan pembelajaran pada pertemuan pertama siklus I ini peserta didik diharapkan dapat ; 1) membandingkan pecahan-pecahan tidak senilai, 2) mengakali berbagai bentuk pecahan, 3) melakukan hitung campuran berbagai bentuk pecahan, 4) memcahkan masalah sehari-hari yang melibatkan pecahan. Tahap pelaksanaan ini terdiri tiga kegiatan yaitu pendahuluan, inti dan penutup.

Guru menyampaikan tujuan pembelajaran yang harus dicapai pada materi yang akan dibahas, dengan metode Tanya jawab guru bertanya tentang tentang perkalian pecahan campuran dan perkalian berbagai bentuk pecahan, kemudian guru membagi peserta didik menjadi beberapa kelompok kecil waktu 10 menit. Peserta didik diberi stimulus atau rangsangan untuk memusatkan perhatian pada materi tentang perkalian pecahan campuran melalui pendekatan saitifik (mengamati, menanya, mengumpulkan informasi / ekperimen, mengasosiasikan mengolah informasi, dan mengkomunikasikan). Peserta didik bersama kelompoknya melakukan pengamatan dari permasalahan yang ada di buku paket dengan materi perkalian pecahan campuran. Guru membagikan tugas kepada kelompok untuk mendiskusikan. Dalam berdiskusi kelompok peserta didik masih ada yang tidak mendengarkan intruksi guru, salah satunya dari kelompok dua dia masih saja tidak acuh dalam kelompoknya ketika berdiskusi, dan dalam kelas ada kelompok yang focus dan juga tidak mau tau dengan diskusi kelompoknya. Selesai diskusi masing-masing kelompok mempresentasekan hasil diskusinya kedepan kelas, kelompok lain menganggapi.Guru memberikan penilaian kelompok waktu 30 menit. Pembenaran hasil diskusi oleh guru dan menambahkan keterangan serta menyimpulkan materi pembelajaran bersama peserta didik waktu 10 menit. Guru dan peserta didik menarik kesimpulan tentang poin-poin penting yang muncul dalam kegiatan pembelajaran yang baru dilakukan tentang perkalian pecahan campuran peserta didik bertanya tentang hal yang belum dipahami atau guru menyampaikan beberapa pertanyaan pemicu kepada peserta didik berkaitan dengan yang akan selesai dipelajari.

Pertemuan kedua siklus I dilaksnakan pada hari Rabu tanggal 29 September 2021di kelas V SDN 146/X Tanjung Solok. Materi yang dibahas adalah "perkalian berbagai bentuk pecahan". Tujuan pembelajaran pada pertemuan dua siklus I ini adalah, peserta didik diharapkan dapat; 1) membandingkan pecahan-pecahan tidak senilai, 2) mengkali berbagai bentuk pecahan, 3) melakukan hitung campuran, 4) memcahkan masalah sehari-hari yang ,eibatkan pecahan. Pertemuan kedua siklus I terdiri dari tiga tahapan yaitu kegiatan pendahuluan, inti dan penutup.

Pada kegiatan ini peserta didik berada dalam kelompok masing-masing. Peserta didik diberi stimulus atau rangsangan untuk memusatkan perhatian pada perkalian berbagai bentuk pecahan 
melalui pendekatan saintifik. Peserta didik melakukan pengamatan dari permasalahan yang ada di buku paket berkaitan dengan materi. Guru mengajak peserta didik untuk mengamati beberapa contoh perkalian berbagai bentuk yang disajikan di buku peserta didik. Guru memberikan kesempatan kepada peserta didik untuk mengidentifikasi aneka pertanyaan yang berkaitan dengan tayangan yang disajikan dan dijawab melalui kegiatan pembelajaran perkalian bentuk pecahan. Peserta didik diarahkan untuk mengumpulkan dan mengekplorasi data dari aneka sumber yang akan digunakan untuk menyelesaikan permasalahan di LKPD. Dengan ditanggapi aktif oleh peserta didik dari kelompok lainnya sehingga diperoleh sebuah pengetahuan baru yang dapat dijadikan sebagai bahan diskusi kelompok kemudian, dengan menggunakan metode ilmiah yang terdapat pada buku pegangan peserta didik atau pada lembar kerja yang disediakan dengan cermat untuk mengembangkan sikap teliti, jujur,sopan, menghargai pendapat orang lain, kemampuan berkomunikasi, menerapkan kemampuan mengumpulkan informasi melalui berbagai cara yang dipelajari, mengembangkan kebiasaan belajar dan belajar sepanjang hayat.

\section{Observasi}

Setelah diadakan tahap pelaksanaan dan diakihiri dengan tes yang berguna untuk melihat hasil belajar peserta didik melalui model pembelajaran discovery learning pada mata pelajaran Matematika peserta didik kelas V SDN 146/X Tanjung Solok. Hasil observasi dapat dilihat pada tabel berikut ini.

Tabel 2. Rekapitulasi Hasil Tes Formatif Pada Siklus I

\begin{tabular}{|l|l|l|}
\hline No. & Uraian & Hasil Siklus I \\
\hline \hline 1. & Nilai rata-rata tes formatif & 56.67 \\
\hline 2. & Nilai tertinggi & 80 \\
\hline 3. & Nilai terendah & 40 \\
\hline 4 & Jumlah peserta didik yang tuntas belajar & 9 \\
\hline 5 & Persentase ketuntasan belajar & 43 \\
\hline
\end{tabular}

Berdasarkan tabel di atas dapat dismpulkan bahwa rata-rat tes formatif peserta didik sebesar 56.67 masih berada dibawah KKM (68) yang ditentukan, sedangkan persentase ketuntasan peserta didik sebesar $43 \%$ atau 9 orang peserta didik dari 21 orang sudah tuntas belajar, namun hal ini belum mencapai target yang diiginkan yaitu $75 \%$.

\section{Refleksi}

Tahap refleksi siklus I dilaksanakan pada hari Kamis tanggal 30 September 2021 dengan dibantu oleh observer yang bernama Neni Rosita, S.Pd. SD dab bertempat di ruangan kelas V SDN 146/X Tanjung Solok. Berdasarkan hasil pengamatan atau observasi, maka dilakukan refleksi terhadap hasil belajar peserta didik setiap pertemuan pada siklus I, dimana perolehan hasilnya belum mencapai KKM yang ditentukan, karena proses pembelajaran belum maksimal. Hasil refleksi hasil belajar peserta didik adalah sebagai berikut:

Dalam proses pembelajaran pada kegiatan ini, setelah peserta didik melakukan presentasi laporan kerjanya, seharusnya guru memperjelas kembali materi yang dibahas oleh peserta didik , 
tetapi tidak maksimal karena : a) Guru kurang menguasai materi, b) Guru kurang maksimal mengatur setting latihan, menyebabkan peserta didik kurang kerja sama dalam kelompok saat melakukan investigasi, kurang disiplin, kurang bertanggung jawab dan kurang menghargai pendapat orang lain (teman kelompok), c) Guru kurang efektif mengelola kelas, karena peserta didik meribut saat mengemukakan pendapat, menulis laporan dan saat mempresentasikan hasil laporan. Hasil refleksi diatas menjadi pedoman untuk dilakukan perbaikan pada siklus II, sehingga terjadi peningkatan hasil belajar peserta didik. Untuk itu penelitian ini dilanjutkan ke siklus berikutnya dengan tindakan pemberian reward.

\section{Siklus II}

\section{Perencanaan}

Pada Tahap perencanaan pada siklus II terdiri dari: 1) Merencanakan materi yang akan dilaksanakan pada waktu penelitian agar mengetahui kompetensi dasar yang akan disampaikan kepada peserta didik dalam pembelajaran, 2) Mempersiapkan silabus dan RPP, 3) Mempersiapkan rencana pembelajarandengan mengacu pada tindakan yang diterapkan dalam PTK, 4) Mempersiapkan media yang akan dipakai pada saat penelitian, 5) Mempersiapkan format Observasi.

\section{Pelaksanaan}

Pertemuan pertama siklus II dilaksanakan pada hari Rabu tanggal 13 Oktober 2021 dengan materi tentang "pembagian pecahan biasa dengan bilangan cacah dan sebaliknya". Tujuan pembelajaran pada pertemuan pertama siklus II ini adalah agar peserta didik dapat; 1) membagi berbagai bentuk pecahan, 2) melakukan hitung campuran berbagai bentuk pecahan, 3) memecahkan masalah sehari-hari yang melibatkan pecahan. Pertemuan pertama ini terdiri dari tiga kegiatan yaitu kegiatan pendahuluan, inti dan penutup.

Peserta didik diberi stimulus atau rangsangan untuk memusatkan perhatian pada materi pembagian pecahan biasa dengan bilangan cacah dan sebaliknya melalui pendekatan saintifik. Peserta didik bersama kelompoknya melakukan pengamatan dari permasalahan yang ada di buku paket dengnan materi. Guru memberikan kesempatan pada peserta didik untuk mengidentifikasi aneka pertanyaan yang berkaitan dengan tayangan yang disajikan dam dijawab melalui kegiatan pembelajaran pembagian pecahan biasa dengan bilangan cacah dan sebaliknya. Peserta didik diarahkan untuk mengumpulkan dan mengeksplorasi data dari aneka sumber yang akan digunakan untuk menyelesaikan permasalahan di LKPD.

Pertemuan kedua siklus II dilaksanakan pada hari Rabu tanggal 27 Oktober 2021 pada jam 07.30 - 09.05 WIB dengan materi membahas tentang pembagian bilangan cacah oleh pecahana campuran dan sebaliknya. Tujuan pembelajaran pada pertemuan kedua siklus II ini adalah agar peserta didik; 1) membagi berbagai bentuk pecahan, 2) melakukan tugas hitungan campuran berbagai bentuk pecahan, 3) memecahkan masalah sehari-hari yang melibatkan pecahan. Pada pertemuan ini tediri dari tiga tahapan yaitu kegiatan pendahuluan, kegiatan inti dan penutup. 
Upaya Meningkatkan Hasil Belajar Peserta Didik pada Muatan Matematika Melalui Model Discovery Learning di Kelas V SDN 146/X Tanjung Solok pada Semester Ganjil Tahun Ajaran 2021/2022, Sahriani

Kegiatan inti, guru membagi peserta didik dalam 5 kelompok yang beranggotakan 4-5 orang.Kemudian peserta didik berkumpul dan mengatur tempat duduk sesuai dengan kelompoknya masing-masing.Secara berkelompok peserta didik dibagi lembar kerja diskusi.Peserta didik melakukan diskusi kelompok.Kegiatan diskusi berjalan dengan baik, peserta didik aktif dalam diskusi kelompok. Hasil diskusi yang sudah dilakukan peserta didik secara berkelompok ditulis pada lembar yang sudah disiapkan.Guru mengajukan pertanyaan yang sudah dibuat sebelum kegiatan pembelajaran dimulai, dan peserta didik berusaha untuk menjawab. Setelah itu dilakukan perputaran peran agar peserta didik dapat mengajukan pertanyaan yang sudah di buat setelah kegiatan diskusi kelompok.Saat salah satu peserta didik mengajukan pertanyaan.Motivasi selalu diberikan guru agar peserta didik berani mengajukan pertanyaan maupun manjawab pertanyaan. Peserta didik yang kurang aktif dalam kegiatan tanya jawab diberikan banyak kesempatan agar kegiatan pembelajaran tidak didominasi oleh peserta didik tertentu. Guru menghargai setiap usaha peserta didik dalam mengajukan pertanyaan maupun menjawab pertanyaan. Peserta didik mempresentasikan hasil diskusinya, dan peneliti dan kolaborator melihat aktivitas peserta didik selama proses pembelajaran.

\section{Observasi}

Pada akhir proses belajar mengajar peserta didik diberi tes formatif II dengan tujuan untuk mengetahui tingkat keberhasilan peserta didik selama proses belajar mengajar yang telah dilakukan. Instrumen yang digunakan adalah tes formatif II. Adapun data hasil penelitian pada siklus II adalah sebagai berikut.

Tabel 3 Rekapitulasi Hasil Tes Formatif Pada Siklus II

\begin{tabular}{|c|l|l|}
\hline No & \multicolumn{1}{|c|}{ Uraian } & Hasil Siklus II \\
\hline \hline 1 & Nilai rata-rata tes formatif & 75.24 \\
\hline 2 & Nilai tertinggi & 100 \\
\hline 3 & Nilai terendah & 50 \\
\hline 4 & Jumlah peserta didik yang tuntas belajar & 18 \\
\hline 5 & Persentase ketuntasan belajar & $86 \%$ \\
\hline
\end{tabular}

Berdasarkan tabel diatas dapat disimpulkan bahwa rata-rata tes formatif peserta didik pada pertemuan siklus II sudah berada di atas kriteria ketuntasan yang diharapkan atau sudah berada di atas KKM yang ditetapkan yaitu sebesar dengan persentase ketuntasan sebesar $86 \%$ atau 18 orang dari 21 orang peserta didik yang sudah tuntas belajar.

\section{Refleksi}

Tahap refleksi siklus II dilaksanakan pada hari Kamis 28 Oktober 2021 di ruangan kepala SDN 146/X Tanjung Solok dengan dibantu oleh seorang obeserver bernama Neni Rosnita, S.Pd. SD. Berdasarkan hasil pengamatan (observasi) peneliti dengan observer dapat didiskripsikan bahwa pelaksanaan pembelajaran muatan matematika dengan menggunakan model discovery learning pada siklus II dapat meningkatkan hasil belajar peserta didik degan tindakan memberikan reward. Berdasarkan refleksi tersebut, diharapkan kepada guru di SDN 146/X Tanjung Solok dapat 
menerapkan model ini dalam proses pembelajaran agar hasil yang dicapai lebih maksimal. Peneliti mengakhiri penelitian ini dengan perolehan hasil yang lebih baik. Karena hasil yang diperoleh sudah melebihi Kriteria Ketuntasan Minimal.

\section{Diskusi}

Data analisis pengamatan hasil belajar peserta didik dalam pembelajaran muatan matematika dengan menggunakan model pembelajaran discovery learning mengalami peningkatan apabila dibandingkan dengan hasil yang dicapai sebelum menggunakan model ini. Berdasarkan tindakan yang dilakukan selama proses pembelajaran telah terjadi peningkatan aktivitas belajar dengan menggunakan metode model pembelajaran discovery learning pada setiap siklus dalam proses pembelajaran, peserta didik yang memperoleh nilai baik dan sangat baik.

Pada Siklus I hasil belajar peserta didik mengalami peningkatan. Hal ini dapat dilihat pada tabel sebelumnya, yaitu pada siklus I hasil belajar peserta didik menunjukan hasil rata-rata 56.67. Pada siklus 1 jumlah peserta didik yang tuntas mengalami peningkatan sebanyak 9 orang dengan persentase ketuntasan belajar peserta didik sebesar $43 \%$. Pada siklus II hasil belajar peserta didik meningkat menjadi $86 \%$ dengan kualifikasi sangat baik. Sebanyak 18 orang peserta didik tuntas dalam belajar. Namun demikian terdapat 3 orang peserta didik yang belum tuntas. Namun hasil belajar yang diperoleh peserta didik dengan menggunakan model pembelajaran discovery learning ini sudah mencapai KKM yang diharapkan.

Untuk meningkatkan hasil belajar peserta didik maka guru harus mengelola kegiatan pembelajaran yang dapat meningkatkan motivasi peserta didik dalam mengikuti kegiatan pembelajaran secara jarak jauh dan dapat dilakukan mandiri di rumah. Salah satu model pembelajaran yang menuntut keaktifan peserta didik dan dapat dilakukan secara mandiri di rumah adalah melalui Discovery Learning. Hosnan (2016: 85), menyatakan "pembelajaran Discovery Learning adalah suatu model pembelajaran yang dapat mengembangkan cara belajar peserta didik aktif dengan menemukan sendiri, menyelediki sendiri, maka hasil yang akan diperoleh peserta didik dapat bertahan lama dalam ingatan, tidak akan mudah dilupakan oleh peserta didik". Melalui cara belajar menemukan, peserta didik akan dapat berpikir analisis dengan menemukan sendiri jawaban dari permasalahan yang dihadapinya.

\section{KESIMPULAN}

Berdasarkan hasil penelitian dan pembahasan dapat disimpulkan bahwa melalui model pembelajaran discovery learning dapat meningkatkan hasil belajar muatan matematika peserta didik kelas V SDN 146/X Tanjung Solok yang ditandai dengan peningkatan rata-rata hasil belajar dan persentase ketuntasan masing-masing siklus dengan tindakan pemberian reward. Berdasarkan hasil penelitian, terdapat beberapa saran yang perlu dipertimbangkan oleh guru dalam menerapkan model discovery Learning untuk meningkatkan hasil belajar peserta didik yaitu: 1) Guru harus lebih memperhatikan kegiatan peserta didik saat berdiskusi, supaya peserta didik dapat lebih focus dan 
Upaya Meningkatkan Hasil Belajar Peserta Didik pada Muatan Matematika Melalui Model Discovery Learning di Kelas V SDN 146/X Tanjung Solok pada Semester Ganjil Tahun Ajaran 2021/2022, Sahriani

berperan aktif dalam berdiskusi, 2) Penggunaan alokasi waktu dan pengelolaan kelas harus benarbenar diperhatikan agar pelaksanaannya dapat berjalan dengan baik dan maksimal, 3) Membuat media pembelajaran yang lebih menarik agar peserta didik lebih focus terhadap materi yang diajarkan, 4) Untuk lebih memahami metode pembelajaran yang aktif dan menarik, disarankan kepada guru untuk mengikuti pelatihan, MGMP, serta seminar yang berkaitan dengan metode pembelajaran.

\section{REFERENSI}

Abdullah Sani, Ridwan. (2013). Inovasi Pembelajaran. Jakarta : Bumi Aksara

Abdullah, Sani Ridwan. (2014). Pembelajaran saintifik untuk kurikulum 2013. Jakarta: Bumi Aksara

B. Uno, Hamzah. (2012). Teori Motivasi dan Pengukurannya. Jakarta : Bumi. Aksara.

Dimyati dan Mudjiono.(2009). Belajar dan Pembelajaran. Jakarta: PT Rineka Cipta

E. Mulyasa. (2003). Manajemen Berbasis Madrasah, Konsep Strategi dan Implementasi. Bandung: Rosdakarya

Fatimah, Sari. 2013. Pengembangan Kompetensi Berpikir Divergen dan Kritis Melalui Pemecahan Masalah Matematika Open-Ended. Jurnal Pendidikan Matematika, (Online), (http://jurnal.upi.edu) diakses 28 April 2016.

Hosnan. (2016). Pendekatan Saintifik dan Konstekstual Dalam Pembelajaran Abad 21. Bogor: Ghalia indonesia.

Kunandar. (2013). Penilaian Authentik (Penilaian Hasil Belajar Peserta Didik Berdasarkan Kurikulum 2013). Jakarta: Rajawali Pers.

Markaban. (2008). Model Penemuan Terbimbing Pada Pembelajaran Matematika di SMK. Yogyakarta: PPPPTK Matematika.

Mustaqim dan Abdul Wahib. (2010). Psikologi Pendidikan. Jakarta : Rineka Cipta.

Nana Sudjana (2010). Dasar-dasar Proses Belajar. Sinar Baru Bandung. Cerdas Berhitung BSE

Ngalim Purwanto. (2007). Psikologi Pendidikan. Bandung: PT Remaja.

Ratna Wilis. (2012). Teori - teori Belajar. Bandung: Erlangga

Roestiyah NK. (2001). Srategi Belajar Mengajar. Jakarta: Rineka Cipta

Roestiyah. (2008). Strategi Belajar Mengajar. Jakarta: Rineka Cipta.

Rusman. (2012). Model Pembelajaran Kooperatif. Jakarta: Balai Pustaka

Rusyanti, Hetty. 2014. "Pengertian Pembelajaran Matematika", online. (http://www.kajianteori.com/2014/02/pengertian-pembelajaran-matematika.html), diakses pada 21 April 2016

Safarida. 2011. Peningkatan Hasil Belajar Matematika Pokok Bahasan Luas Persegi dan Persegi Panjang Melalui Pendekatan Mastery Learning. Jurnal Ilmu Pendidikan, (Online), (http://admathedu.uad.ac.id/) diakses 09 Februari 2016.

Sardiman. (2008). Interaksi dan Motivasi Belajar Mengajar. Jakarta: Raja Grafindo. Persada

Slameto. (2010). Belajar dan Faktor yang mempengaruhinya. Jakarta: Rineka. Cipta. Sriyono. 
Sudiati, Sri. 2014. "Pengertian Pembelajaran Matematika", online. (http://www.srisudiati.namablogku.com/2014/05/ pembelajaran-matematika-di-sekolah.html), diakses pada 18 April 2016.

Sudjana. (2005). Metode Statistika. Bandung: Tarsito.

Trianto. (2010). Mendesain Model Pembelajaran Inovatif-Progresif: Konsep, Landasan, dan Implementasinya pada Kurikulum Tingkat Satuan Pendidikan (KTSP). Jakarta : Kencana.

Uno, H. (2011). Teori Motivasi dan Pengukurannya. Jakarta: PT Bumi Aksara Bandung

Usman, Racmadi. (2001). Aspek-aspek Hukum Perbankan di Indonesia. Jakarta: PT. Gramedia Pustaka Utama

Wahidmurni, dkk. (2010). Evaluasi Pembelajaran. Yogyakarta: Nuha Litera. 